\title{
Parasite biodiversity and its determinants in coastal marine teleost fishes of Brazil
}

\author{
J. L. LUQUE ${ }^{1}$, D. MOUILLOT ${ }^{2}$ and R. POULIN ${ }^{3 *}$ \\ ${ }^{1}$ Departamento de Parasitologia Animal, Universidade Federal Rural do Rio de Faneiro, Caixa Postal 74.508, \\ CEP 23851-970, Seropédica, RF, Brazil \\ ${ }^{2}$ UMR CNRS-UMII 5119 Ecosystèmes Lagunaires, Université Montpellier II, CC 093, 34095 Montpellier cedex 5, France \\ ${ }^{3}$ Department of Zoology, University of Otago, P.O. Box 56, Dunedin, New Zealand
}

(Received 20 October 2003; revised 14 November 2003; accepted 29 November 2003)

\section{SUMMARY}

Recent studies of the forces behind the diversification of parasite assemblages have shed light on many aspects of parasite biodiversity. By using only parasite species richness as their measure of diversity, however, previous investigations have ignored the relatedness among parasite species and the taxonomic structure of the assemblages, which contain much information about their evolutionary origins. Here, we performed a comparative analysis across 50 species of fish from the coast of Brazil; we evaluated the effects of several host traits (body size, social behaviour, feeding habits, preference for benthic $v s$. pelagic habitats, depth range, and ability to enter brackish waters) on the diversity of their assemblages of metazoan parasites. As measures of diversity, we used parasite species richness, as well as the average taxonomic distinctness of the assemblage and its variance; the latter measures are based on the average taxonomic distance between any two parasite species in an assemblage. Unlike parasite species richness, taxonomic distinctness was unaffected by the number of host individuals examined per species. Fish body length proved to be the main predictor of parasite species richness, even when controlling for the confounding influences of host phylogeny and sampling effort, although it did not correlate with measures of parasite taxonomic distinctness. Predatory fish also had higher parasite species richness than planktivores, but this trend could not be confirmed using phylogenetically independent contrasts between host taxa. The main host feature associated with the taxonomic diversity of parasites was schooling behaviour, with schooling fish having more taxonomically diverse parasite assemblages than those of their non-schooling relatives. When focusing on endoparasite species only, both predatory feeding habits and a broad depth range were associated with the taxonomic distinctness of parasites. Our results suggest that certain host traits (i.e. body size) determine how many parasite species a host can accumulate over evolutionary time, whereas different host features influence the processes causing the taxonomic diversification of parasite assemblages.

Key words: comparative analysis, host phylogeny, taxonomic distinctness.

\section{INTRODUCTION}

Parasite assemblages are playing an increasingly important role as models for the study of biodiversity and biogeography (Poulin \& Morand, 2000). The events leading to new species joining parasite assemblages are relatively well understood, and it is possible to search for the key factors that have caused certain parasite assemblages to diversify more than others over evolutionary time (Poulin, 1998; Page, 2003). Yet, the results currently available are inconsistent (Poulin, 1997; Morand, 2000). In fish, for instance, some comparative studies have found that host body size is a good predictor of parasite species richness (Price \& Clancy, 1983; Bell \& Burt, 1991; Poulin, 1995; Gregory, Keymer \& Harvey, 1996; Sasal, Morand \& Guégan, 1997) whereas others have

* Corresponding author: Department of Zoology, University of Otago, P.O. Box 56, Dunedin, New Zealand. Tel: +6434797983. Fax: +6434797584. E-mail: robert.poulin@stonebow.otago.ac.nz found no effect of host size (e.g., Morand et al. 2000, though this study focused on a single fish family). The same is true for a range of other host features (see Poulin, 1997; Morand, 2000). It is therefore difficult to assess the relative importance of different host traits for the evolution of parasite diversity in general.

One reason for the inconsistent results may be that most data sets used in previous analyses have been compiled from many different sources. The differences in the methods used to detect and identify parasites among different sources can generate too much error and statistical noise for any existing signal to emerge. In addition, the different host species included in the same data set often come from different geographical areas; availability of (and exposure to) different parasite species varies across regions, adding another element of variability to such data sets. Ideally, one would examine interspecific variation in parasite diversity among a group of host species from the same area, all examined in a standard way by the same researcher(s). 
Another reason why previous results have been inconsistent may be that the measure of parasite diversity used in earlier studies is not the most appropriate one. To date, all have used species richness as their sole measure of the diversity of parasite assemblages. Richness is a convenient measure, but it does not capture all facets of diversity (Purvis \& Hector, 2000). It ignores the evolutionary relationships among species coexisting in an assemblage (see Shimatani, 2001). Applied to parasite assemblages, measures of diversity that incorporate information on the relationships among parasite species can shed light on how the assemblage has formed. New species join a parasite assemblage in one of two ways (Poulin, 1998; Page, 2003). First, they can originate from within the assemblage by intra-host speciation, when one parasite species undergoes speciation without the host also speciating. The large numbers of congeneric parasite species occurring in certain assemblages indicate that parasite lineages can radiate within single host species over time (Schad, 1963; Kennedy \& Bush, 1992; Beveridge, Chilton \& Spratt, 2002). Second, new parasite species can arrive when a parasite from a sympatric host species colonizes the assemblage by switching hosts (Paterson \& Gray, 1997). Studies of parasite diversity that focus on species richness cannot distinguish between the different origins of parasite species in an assemblage. If the parasites in an assemblage form a narrow taxonomic grouping, intra-host speciation may have been common, or the host has only been colonized by parasites from a limited taxonomic spectrum. If, in contrast, the parasites in an assemblage are completely unrelated, then the assemblage has formed by repeated colonizations from a broad taxonomic range of parasites, indicating that the host is a 'magnet' for many types of parasites. We need a measure of diversity that goes beyond mere species richness, a measure that takes into account the relationships between parasite species in an assemblage if we are to figure out which host features attract parasites.

Predictions about which host features may promote the diversification of parasite assemblages have come from two different theoretical frameworks. First, following from island biogeographical theory (MacArthur \& Wilson, 1967; Kuris, Blaustein \& Alió, 1980), host features that promote high rates of parasite speciation or colonization by new parasite species should be associated with high parasite diversity. For instance, larger-bodied hosts should be able to accommodate more parasite species than small ones; they may also incur higher exposure to internal parasites because of the quantities of food they ingest, and to external parasites because their larger surface area facilitates contact with infective stages. Other host features that increase exposure to different kinds of parasites should also lead to higher colonization rates. These include a broad geographical range that overlaps with the distributions of several other host species, from which new parasite species can be acquired, as well as the type and breadth of habitats used by the host. Empirical support exists for most of these variables, but with the inconsistencies alluded to above (see reviews in Poulin, 1997; Morand, 2000).

The second theoretical source of predictions regarding parasite diversity has been epidemiological modelling (Dobson \& Roberts, 1994; Roberts et al. 2002). The models indicate that host population density, which regulates the contact rate between parasite infective stages and hosts, is the key factor determining whether a parasite species can invade and persist in a host population. In comparisons among different host species, those occurring at higher population density should harbour more species of parasites, because they exceed the persistence threshold of more parasite species than hosts with low population density. Comparative studies on mammals have found empirical support for this prediction (Morand \& Poulin, 1998; Arneberg, 2002). In hosts such as fish, social behaviour determines host density. Many workers have found that schooling fish species are used by more species of parasites than solitary species, for both external parasites (Caro, Combes \& Euzet, 1997; Sasal \& Morand, 1998; Raibaut, Combes \& Benoit, 1998) and all parasites combined (Ranta, 1992).

All the host features mentioned above are expected to influence parasite species richness; what is not known is how they should affect the taxonomic structure of the parasite assemblage. Certain host traits may promote the acquisition of a broad taxonomic range of parasite species, whereas other host traits may lead to the acquisition of the same number of parasite species, but from a narrower taxonomic spectrum. In the present study, we examine the relationship between different features of host species and the diversity of metazoan parasite assemblages across species of fish hosts from Brazilian coastal waters. We use two measures of diversity, parasite species richness and the taxonomic distinctness of species within an assemblage. The latter measure is based on the average taxonomic distances between parasite species (Clarke \& Warwick, 1998, 1999; Warwick \& Clarke, 2001). Our study is the first to use indices of taxonomic distances as measures of parasite diversity.

MATERIALS AND METHODS

\section{Data collection}

All fish were collected by local fishermen from the coastal waters off the state of Rio de Janeiro, Brazil (latitude $21-23^{\circ} \mathrm{S}$ ), during the period 1991 to 2002 . The fishes were identified according to Figueiredo \& Menezes (1978, 1980, 2000) and Menezes \& Figueiredo (1980, 1985). Each individual fish was measured (total length) and examined for both 
external and internal metazoan parasites, using standard parasitological methods. All internal organs were searched for endoparasites; washings from the gills and the lumen of the gut were passed through a sieve $(154 \mu \mathrm{m}$ mesh size $)$ to recover even the smallest parasites (further methodological details provided in the references at the end of this paragraph). The metazoan parasites recovered consisted of platyhelminths (trematodes, cestodes, monogeneans), nematodes, acanthocephalans, hirudineans and crustaceans. All fish dissections and collection of the parasites were made using the same methods, and all parasite identifications were carried out or confirmed by the same person (J.L.L.). Thus the data do not suffer from the problems associated with data sets compiled from different sources and based on different methods. Quantitative information on the prevalence and intensity of infection by different parasites and on parasite community descriptors has been published previously for about half of the fish species in our data set (Luque et al. 1996, 2000, 2002, 2004; Takemoto, Luque \& Amato, 1996; Knoff, Luque \& Amato, 1997; Cezar \& Luque, 1999; Chaves \& Luque, 1999; Luque \& Chaves, 1999; Silva et al. 2000; Luque \& Alves, 2001; Tavares et al. 2001, $2004 a, b$; Alves \& Luque, 2001; Alves et al. $2002 a$, $b$; Paraguassú, Luque \& Alves, 2002; Cordeiro \& Luque, 2004; Tavares \& Luque, 2004a,b). The present analysis is the first one that combines all these data; the entire data set is shown in Table 1.

For each host species, the total number of fish examined for parasites and the total number of parasite species (i.e. parasite species richness) found were recorded. The number of hosts examined, or sampling effort, is often a key determinant of the number of parasites found in a survey (Walther et al. 1995), and must therefore be included as a potential confounding variable. For the computations of taxonomic distinctness (see below), we used the proposed taxonomies of Brooks \& McLennan (1993) and Gibson, Jones \& Bray (2002) for trematodes, Boeger \& Kritsky (1993) for monogeneans, Khalil, Jones \& Bray (1994) for cestodes, Amin (1985) for acanthocephalans, Anderson (2000) for nematodes, Apakupakul, Siddall \& Burreson (1999) for hirudineans, Boxshall \& Montú (1997) for copepods, Yamaguti (1963) for branchiurans, and BunkleyWilliams \& Williams, Jr. (1998) for isopods.

In addition to data on average host body length obtained from the individual fish examined, data on a range of variables were also obtained from Haimovici, Martins \& Vieira (1996), Carvalho Filho (1999), Bizerril \& Costa (2001), and Froese \& Pauly (2003), giving priority to the former three as they deal specifically with fish in Brazilian waters. The following variables were recorded for each fish species: (1) whether the fish species forms schools or not, with species adopting schooling only in some parts of the year (e.g. during the reproductive period) classified as schooling; (2) whether its geographical distribution extends to the Atlantic coast of South America (mainly Brazil), the Atlantic coast of both North and South America, or the whole world; (3) whether the fish's habitat is benthic, benthopelagic or pelagic; (4) whether or not it occasionally enters brackish or estuarine waters; (5) whether it is a predator (the majority of species) or a planktivore; and (6) its depth range, measured as the difference between the deepest and shallowest depths at which it occurs.

\section{Taxonomic distinctness of parasite assemblages}

For each fish species, we computed the average taxonomic distinctness $\left(\Delta^{+}\right)$and the variance in taxonomic distinctness $\left(\Lambda^{+}\right)$of the parasite species found. This was done in three ways for each fish species: for all parasite species, for endoparasites (trematodes, cestodes, acanthocephalans and nematodes) only, and for ectoparasites (monogeneans, hirudineans and crustaceans) only. Taxonomic distinctness measures for endoparasites and ectoparasites were only computed for fish species harbouring at least 4 parasites of either type, because values obtained for fewer parasite species are not reliable.

When parasite species are placed within a taxonomic hierarchy, based on the Linnean classification into kingdom, phyla, classes, orders, families, genera and species, the average taxonomic distinctness, $\Delta^{+}$, is simply the mean number of steps up the hierarchy that must be taken to reach a taxon common to two parasite species, computed across all possible pairs of parasite species in an assemblage (Clarke $\&$ Warwick, 1998, 1999; Warwick \& Clarke, 2001). Thus, if two species are congeners, one step (species-to-genus) is necessary to reach a common node in the taxonomic tree; if the two species belong to different genera but the same family, two steps will be necessary (speciesto-genus and genus-to-family); and so on, with these numbers of steps averaged across all species pairs. For any given species pair, the number of steps corresponds to half the path length connecting two species in the taxonomic tree, with equal step lengths being postulated between each level in the taxonomic hierarchy. Step lengths are standardized so that the distinctness of two species connected at the highest taxonomic level is set equal to 100 (Clarke \& Warwick, 1999); with 6 levels above the species in the taxonomy we used, each step length was thus equal to 16.67. The greater the taxonomic distinctness between parasite species, the higher the number of steps needed, and the higher the value of $\Delta^{+}$. A high value means that on average the parasites in a host population are not closely related. Formally, $\Delta^{+}$is computed as follows (see Clarke \& Warwick, 1998):

$\Delta^{+}=2 \frac{\sum \sum_{i<j} \omega_{i j}}{s(s-1)}$, 
Table 1. Summary of the data on the 50 Brazilian fish species included in the analyses

\begin{tabular}{|c|c|c|c|c|c|c|c|c|c|c|c|}
\hline $\begin{array}{l}\text { Host } \\
\text { species }\end{array}$ & $\begin{array}{l}\text { Number } \\
\text { fish } \\
\text { examined }\end{array}$ & $\begin{array}{l}\text { Parasite } \\
\text { species } \\
\text { richness* }\end{array}$ & $\Delta^{+}$ & $\Lambda^{+}$ & $\begin{array}{l}\text { Fish body } \\
\text { length } \\
(\mathrm{cm})\end{array}$ & Schooling ?† & $\begin{array}{l}\text { Benthic/ } \\
\text { pelagic§ }\end{array}$ & Brackish ?ף & $\begin{array}{l}\text { Feeding } \\
\text { habits } \dagger \dagger\end{array}$ & $\begin{array}{l}\text { Geographical } \\
\text { range } \S\end{array}$ & $\begin{array}{l}\text { Depth } \\
\text { range } \\
(\mathrm{m})\end{array}$ \\
\hline Aluterus monoceros & 39 & $9(2)$ & $85 \cdot 65$ & $372 \cdot 73$ & $31 \cdot 2$ & 2 & 2 & 2 & 1 & 3 & 79 \\
\hline Anchoa tricolor & 103 & $10(2)$ & $91 \cdot 85$ & $279 \cdot 29$ & $11 \cdot 1$ & 1 & 3 & 1 & 2 & 1 & 19 \\
\hline Archosargus rhomboidalis & 30 & $10(4)$ & $82 \cdot 96$ & $660 \cdot 36$ & $31 \cdot 3$ & 1 & 1 & 1 & 1 & 2 & 14 \\
\hline Balistes capriscus & 66 & $22(4)$ & $89 \cdot 11$ & $262 \cdot 50$ & $35 \cdot 0$ & 1 & 2 & 2 & 1 & 2 & 119 \\
\hline Balistes vetula & 30 & $13(4)$ & $90 \cdot 81$ & $168 \cdot 43$ & $47 \cdot 8$ & 1 & 2 & 2 & 1 & 2 & 273 \\
\hline Brevoortia aurea & 42 & $5(1)$ & $70 \cdot 00$ & $766 \cdot 67$ & $29 \cdot 6$ & 1 & 3 & 2 & 2 & 1 & 4 \\
\hline Caranx hippos & 60 & $19(7)$ & $86 \cdot 84$ & $348 \cdot 31$ & $43 \cdot 9$ & 1 & 3 & 1 & 1 & 2 & 349 \\
\hline Caranx latus & 55 & $17(4)$ & $87 \cdot 01$ & $329 \cdot 62$ & $33 \cdot 3$ & 1 & 3 & 1 & 1 & 2 & 80 \\
\hline Centropoтиs undecimalis & 79 & $9(6)$ & $91 \cdot 20$ & $223 \cdot 55$ & $35 \cdot 2$ & 1 & 1 & 1 & 1 & 2 & 21 \\
\hline Cephalopholis fulva & 30 & $7(2)$ & $94 \cdot 44$ & $246 \cdot 91$ & $20 \cdot 6$ & 2 & 1 & 1 & 1 & 2 & 149 \\
\hline Chaetodipterus faber & 110 & $10(6)$ & $82 \cdot 59$ & $542 \cdot 66$ & $27 \cdot 7$ & 1 & 1 & 2 & 1 & 2 & 32 \\
\hline Cynoscion guatucupa & 73 & $19(5)$ & 88.79 & $256 \cdot 11$ & $32 \cdot 6$ & 1 & 2 & 2 & 1 & 1 & 119 \\
\hline Dactylopterus volitans & 30 & $21(3)$ & $86 \cdot 90$ & $351 \cdot 00$ & $22 \cdot 9$ & 2 & 1 & 1 & 1 & 2 & 99 \\
\hline Diapterus rhombeus & 32 & $6(0)$ & $90 \cdot 00$ & $362 \cdot 96$ & $17 \cdot 4$ & 1 & 1 & 1 & 1 & 2 & 61 \\
\hline Euthynnus alleteratus & 46 & $20(8)$ & $90 \cdot 26$ & $289 \cdot 70$ & $43 \cdot 9$ & 1 & 3 & 1 & 1 & 3 & 149 \\
\hline Genypterus brasiliensis & 55 & $14(3)$ & $91 \cdot 76$ & $301 \cdot 43$ & $42 \cdot 7$ & 2 & 1 & 2 & 1 & 1 & 140 \\
\hline Gymnothorax moringa & 30 & $9(2)$ & $87 \cdot 50$ & $422 \cdot 45$ & $70 \cdot 4$ & 2 & 1 & 2 & 1 & 2 & 199 \\
\hline Haemulon steindachneri & 80 & $18(8)$ & $88 \cdot 56$ & $317 \cdot 61$ & $19 \cdot 6$ & 1 & 1 & 2 & 1 & 2 & 49 \\
\hline Harengula clupeola & 35 & $6(3)$ & $74 \cdot 44$ & $809 \cdot 88$ & $20 \cdot 0$ & 1 & 3 & 1 & 2 & 2 & 29 \\
\hline Macrodon ancylodon & 31 & $19(5)$ & $88 \cdot 79$ & $256 \cdot 11$ & $30 \cdot 0$ & 1 & 1 & 1 & 1 & 1 & 59 \\
\hline Menticirrhus americanus & 115 & $19(6)$ & $86 \cdot 35$ & $294 \cdot 64$ & $28 \cdot 4$ & 1 & 1 & 1 & 1 & 2 & 70 \\
\hline Micropogonias furnieri & 100 & $28(11)$ & $92 \cdot 15$ & $204 \cdot 42$ & $33 \cdot 2$ & 1 & 2 & 1 & 1 & 2 & 119 \\
\hline Mugil platanus & 150 & $25(10)$ & $85 \cdot 89$ & $354 \cdot 58$ & $54 \cdot 8$ & 1 & 2 & 1 & 2 & 1 & 119 \\
\hline Mullus argentinae & 100 & $15(4)$ & $90 \cdot 95$ & $259 \cdot 41$ & $17 \cdot 8$ & 1 & 1 & 2 & 1 & 1 & 110 \\
\hline Netuma barba & 63 & $15(8)$ & $90 \cdot 63$ & $375 \cdot 26$ & $43 \cdot 9$ & 1 & 2 & 1 & 1 & 1 & 119 \\
\hline Oligoplites palometa & 84 & $18(8)$ & $87 \cdot 25$ & $384 \cdot 04$ & $38 \cdot 2$ & 1 & 2 & 1 & 1 & 2 & 27 \\
\hline Oligoplites saliens & 36 & $13(7)$ & $86 \cdot 11$ & $423 \cdot 20$ & $36 \cdot 8$ & 1 & 2 & 1 & 1 & 2 & 39 \\
\hline Oligoplites saurus & 37 & $13(5)$ & $85 \cdot 47$ & $251 \cdot 84$ & $29 \cdot 0$ & 1 & 2 & 1 & 1 & 2 & 39 \\
\hline Orthopristis ruber & 162 & $21(11)$ & $86 \cdot 59$ & $371 \cdot 69$ & $21 \cdot 6$ & 1 & 1 & 1 & 1 & 2 & 69 \\
\hline Pagrus pagrus & 90 & $22(13)$ & $90 \cdot 40$ & $337 \cdot 21$ & $29 \cdot 5$ & 1 & 2 & 2 & 1 & 3 & 249 \\
\hline Paralichthys isosceles & 36 & $15(1)$ & $86 \cdot 98$ & $497 \cdot 25$ & $31 \cdot 2$ & 2 & 1 & 2 & 1 & 1 & 140 \\
\hline Paralonchurus brasiliensis & 93 & $15(4)$ & $92 \cdot 22$ & $264 \cdot 90$ & $21 \cdot 1$ & 1 & 1 & 1 & 1 & 1 & 79 \\
\hline Peprilus paru & 30 & $8(2)$ & $85 \cdot 71$ & $450 \cdot 68$ & $23 \cdot 7$ & 1 & 2 & 1 & 1 & 2 & 121 \\
\hline Percophis brasiliensis & 60 & $11(2)$ & $84 \cdot 55$ & $685 \cdot 40$ & $43 \cdot 6$ & 2 & 1 & 2 & 1 & 1 & 100 \\
\hline Pomatomus saltator & 55 & $16(4)$ & $89 \cdot 58$ & $315 \cdot 10$ & $46 \cdot 6$ & 1 & 3 & 1 & 1 & 3 & 198 \\
\hline Priacanthus arenatus & 58 & $13(5)$ & $93 \cdot 59$ & $243 \cdot 81$ & $37 \cdot 7$ & 1 & 1 & 2 & 1 & 2 & 190 \\
\hline Prionotus punctatus & 47 & $21(5)$ & $90 \cdot 32$ & $324 \cdot 24$ & $29 \cdot 3$ & 2 & 1 & 1 & 1 & 2 & 110 \\
\hline Sardinella brasiliensis & 35 & $2(0)$ & $33 \cdot 33$ & 0 & $18 \cdot 2$ & 1 & 3 & 2 & 2 & 2 & 349 \\
\hline Sciadeichthys luniscutis & 30 & $14(8)$ & $85 \cdot 35$ & $420 \cdot 24$ & $35 \cdot 5$ & 1 & 2 & 1 & 1 & 1 & 29 \\
\hline Scomber japonicus & 100 & $15(5)$ & $90 \cdot 63$ & $385 \cdot 84$ & $25 \cdot 8$ & 1 & 3 & 2 & 1 & 3 & 299 \\
\hline Scomber scombrus & 43 & $3(0)$ & $33 \cdot 33$ & 0 & $23 \cdot 4$ & 1 & 3 & 1 & 1 & 3 & 199 \\
\hline
\end{tabular}


where $s$ is the number of parasite species, the double summation is over the set $\{i=1, \ldots, s ; j=1, \ldots, s$, such that $i<j\}$, and $\omega_{i j}$ is the taxonomic distinctness between parasite species $i$ and $j$, or the number of taxonomic steps required to reach a node common to both.

The index $\Delta^{+}$measures the average taxonomic distinctness between species, and does not capture all of the taxonomic structure of a set of parasite species. It is possible to have two host species, each harbouring the same number of parasite species and each characterized by an identical value of $\Delta^{+}$, but with one host species clearly supporting a broader taxonomic range of parasites. Asymmetries in the taxonomic distribution of parasite species across higher taxa can sometimes be missed by $\Delta^{+}$, which is only the average taxonomic distinctness; in these situations complementary information can be obtained by examining the variance in taxonomic distinctness (see Clarke \& Warwick, 2001; Warwick \& Clarke, 2001):

$\Lambda^{+}=\frac{\sum \sum_{i \neq j}\left(\omega_{i j}-\varpi\right)^{2}}{s(s-1)}$,

where $\varpi$ is simply the average taxonomic distinctness, or $\Delta^{+}$. The variance $\Lambda^{+}$conveys separate information of how much taxonomic heterogeneity there is among a group of parasite species. Note, however, that $\Lambda^{+}$can only be computed when at least 3 parasite species are found in a host species (it always equals zero with 2 species). To calculate $\Delta^{+}$and $\Lambda^{+}$, a computer program was developed (by D.M.) using borland $\mathrm{C}++$ Builder 5.0.

\section{Statistical analyses}

Analyses were performed separately on all parasite species, on endoparasites only, and on ectoparasites only. We analysed our data in two ways, one that highlighted any existing pattern in the distribution of parasite diversity among host species, and one that emphasized which factors played a role in the evolutionary diversification of parasite assemblages. In the first series of analyses, fish species were treated as independent observations, using standard parametric tests on log-transformed continuous variables. In analyses using categorical variables (e.g. schooling behaviour or feeding habits), it was not possible to use multifactorial ANOVAs because there were too few species in some categories and thus too many empty cells in the factorial matrix. Nevertheless, our analyses allowed us to determine which features of host species are associated with either many parasite species or with taxonomically diverse parasite assemblages. In the second round of analyses, we took host phylogeny into account. Closely related host species are likely to harbour a similar number of parasite species, and possibly taxonomically related 
parasite species, because these were inherited from a recent common ancestor; this means that they do not represent truly independent statistical observations. We must therefore control for phylogenetic influences when evaluating the effects of host features (body size, schooling or feeding habits, etc.) on the evolution of parasite assemblages. To achieve this, we used the phylogenetically independent contrasts method (Felsenstein, 1985; Harvey \& Pagel, 1991), implemented with the CAIC version 2.0 program (Purvis \& Rambaut, 1994). Contrasts were derived from a host tree constructed from published studies on the phylogenetic relationships of fish (Nelson, 1994; Carpenter, Collette \& Russo, 1995; Reed, Carpenter \& deGravelle, 2002; Chen, Bonillo \& Lecointre, 2003; Miya et al. 2003). Contrasts were computed on log-transformed data and all regression analyses were forced through the origin (Garland, Harvey \& Ives, 1992). We obtained contrasts corrected for the influence of one or more confounding variables (e.g., sampling effort) by taking the residuals of regressions of a selected variable against the potential confounding variables. For dichotomous variables (schooling behaviour, feeding habit, tolerance of brackish waters), contrasts were computed following Burt (1989). The mean value of these contrasts was compared with zero, as expected from the null hypothesis, using one-group two-tailed $t$-tests.

Because our aim was to expose associations between host features and measures of parasite diversity, we did not apply a Bonferroni correction to our results. Applying the correction could possibly mask interesting trends worthy of further investigation (Moran, 2003).

\section{RESULTS}

In total, data from 50 fish host species were obtained (see Table 1). These data were derived from the examination of 3067 individual fish, for an average of 61 hosts per species (range 30 to 162). The number of host species (or sets of independent contrasts) varies among the analyses reported below, because of some missing data on certain variables for a few fish species.

Using data on all metazoan parasites across all fish species, the number of hosts examined per species correlated positively with parasite species richness $(r=0.453, N=50, P=0 \cdot 0009)$, but not with either $\Delta^{+}(r=0 \cdot 196, N=50, P=0 \cdot 1723)$ or $\Lambda^{+}(r=-0 \cdot 194$, $N=48, P=0 \cdot 1874)$. Measures of taxonomic distinctness are thus independent of sampling effort, as shown in earlier studies (Rogers, Clarke \& Reynolds, 1999). However, parasite species richness correlated positively with $\Delta^{+}(r=0 \cdot 679, N=50, P=0 \cdot 0001)$ and negatively with $\Lambda^{+}(r=-0 \cdot 374, N=48, P=0 \cdot 0087)$, indicating that measures of taxonomic distinctness are influenced by the number of parasite species in a sample. Also, $\Delta^{+}$and $\Lambda^{+}$covaried negatively

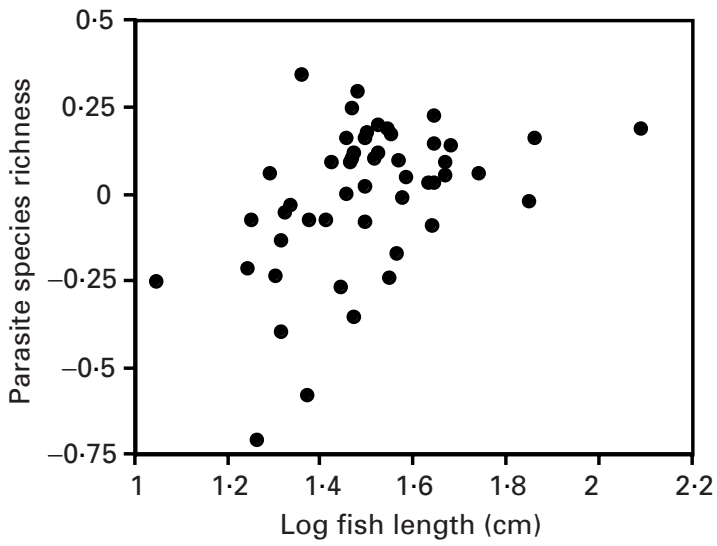

Fig. 1. Relationships between metazoan parasite species richness and length of the host fish species, across 50 fish species. Measures of species richness are residuals of the regression of log species richness against log number of fish examined, and are thus corrected for host sampling effort.

$(r=-0 \cdot 774, N=48, P=0 \cdot 0001)$, such that an increase in average taxonomic diversity is associated with a decrease in its variance. Identical patterns were also found using phylogenetic contrasts, and the relationships generally hold using either only endoparasites or only ectoparasites, with minor exceptions. Thus, in all comparative analyses below, parasite species richness is corrected for sampling effort, and $\Delta^{+}$and $\Lambda^{+}$are always corrected for parasite species richness, when appropriate.

\section{Diversity of all metazoan parasites}

Using species values as independent statistical observations, we found that fish length correlated positively with parasite species richness $(r=0 \cdot 445, N=$ $50, P=0 \cdot 0012)$ : larger fish species tended to harbour more parasite species, independently of sampling effort (Fig. 1). In fact, as seen in Fig. 1, the relationship is better explained by a curvilinear regression with a quadratic term $\left(r^{2}=0 \cdot 236, P=0 \cdot 0018\right)$ than by a linear relationship $\left(r^{2}=0 \cdot 198, P=0 \cdot 0012\right)$, suggesting there may be a threshold size beyond which parasite species richness stops increasing. No such correlation with fish length was found when using either $\Delta^{+}(r=-0 \cdot 122, N=50, P=0 \cdot 3984)$ or $\Lambda^{+}(r=$ $0 \cdot 178, N=48, P=0 \cdot 2266)$ as measure of parasite diversity. Host depth range did not correlate with parasite species richness $(r=0 \cdot 076, N=49, P=0 \cdot 6057)$, but it covaried negatively, though weakly, with $\Delta^{+}$ $(r=-0 \cdot 272, N=49, P=0 \cdot 0582)$ and $\Lambda^{+}(r=-0 \cdot 318$, $N=47, P=0 \cdot 0293)$. In other words, fish species occurring over a narrow range of depths tend to possess a taxonomically more diverse parasite fauna than fish with a broad depth range. The effect of other host features on parasite diversity was evaluated with ANOVAs, given that fish species fell into different categories. Only two significant results were obtained: parasite species richness varied significantly 

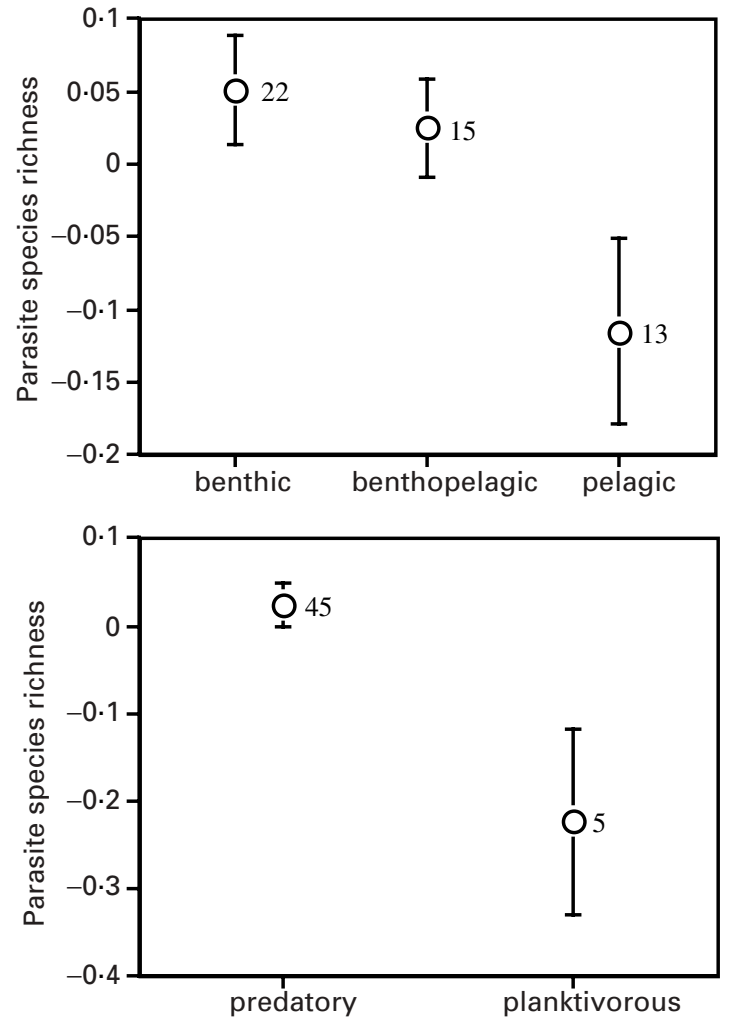

Fig. 2. Mean ( \pm s.E.) parasite species richness in fish species found at different heights in the water column (top), and in fish species with different feeding habits (bottom). Measures of species richness are residuals of the regression of $\log$ species richness against $\log$ number of fish examined and log fish length, and are thus corrected for both host sampling effort and host size. Numbers of fish species in each category are shown on the graphs.

among fish species inhabiting different parts of the water column (benthic, benthopelagic and pelagic) $\left(F_{2,47}=3 \cdot 665, P=0.0332\right)$ and between predatory and planktivorous fish species $\left(F_{1,48}=8 \cdot 893, P=0 \cdot 0045\right)$. Benthic and predatory fish harboured more parasite species than pelagic or planktivorous fish (Fig. 2), even after controlling for the effects of sampling effort and fish length. The extent of the geographical distribution of the fish, and whether or not they can enter brackish habitats, had no effect on any of the measures of parasite diversity. The same was true of schooling behaviour, although non-schooling fish species tended to have lower values of $\Lambda^{+}$than schooling species $\left(F_{1,46}=3 \cdot 582, P=0 \cdot 0647\right)$.

Results obtained when using phylogenetically independent contrasts show some similarities to those obtained from analyses of raw species values. Again, fish length correlated positively with parasite species richness (Fig. $3 ; r=0 \cdot 381, N=40$ sets of contrasts, $P=0 \cdot 0153$ ), but not with either $\Delta^{+}$or $\Lambda^{+}$(both $P>$ $0 \cdot 40)$. Host depth range correlated negatively with only one of the three measures of parasite diversity, $\Lambda^{+}(r=-0 \cdot 452, N=37$ sets of contrasts, $P=0 \cdot 0051)$, but once an outlier was excluded from the analysis, the relationship disappeared $(P=0 \cdot 2664)$. It was not

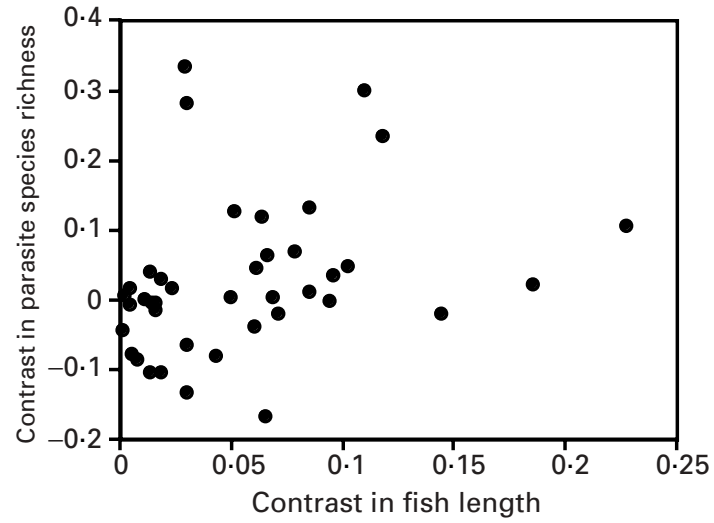

Fig. 3. Metazoan parasite species richness (corrected for sampling effort) as a function of host body length across fish host species, based on 40 phylogenetically independent contrasts.

possible to confirm or refute the effect of feeding habits on parasite diversity, as shown in Fig. 2, because there were only two independent contrasts between fish taxa with different feeding modes. There were no effects, however, of either geographical distribution, use of benthic $v s$. pelagic habitats, or ability to enter brackish waters, on parasite diversity (all $P>0 \cdot 19$ ). Interestingly, in the contrasts between schooling and non-schooling fish taxa, there was evidence that schooling fish had higher values of $\Lambda^{+}$ than non-schooling taxa $(t=2 \cdot 377, N=8$ sets of contrasts, $P=0 \cdot 0491$ ), as seen in the analysis using fish species values instead of contrasts. In other words, the variance in taxonomic distinctness of parasite assemblages of schooling fish was higher than that of their non-schooling relatives.

\section{Diversity of endoparasites}

Using host species values as independent observations, we found no correlation between fish length and either endoparasite species richness, $\Delta^{+}$, or $\Lambda^{+}$ (all $P \geqslant 0 \cdot 19$ ). Host depth range correlated positively with endoparasite species richness $(r=0 \cdot 482, N=45$, $P=0 \cdot 0008$ ), but not with either $\Delta^{+}$or $\Lambda^{+}$(both $P \geqslant 0 \cdot 13$ ); this pattern changes when host phylogeny is taken into account (see below). Of the categorical variables considered, only one was associated with endoparasite diversity: endoparasite $\Delta^{+}$varied significantly between predatory and planktivorous fish species $\left(F_{1,44}=6 \cdot 957, P=0 \cdot 0115\right)$. Despite very unequal sample sizes, predatory fish harboured endoparasite species that are more taxonomically diverse than those of planktivorous fish (Fig. 4), even after controlling for the effects of species richness.

Results obtained when using phylogenetically independent contrasts confirmed the absence of a relationship between fish length and any of the three measures of endoparasite diversity (all $P \geqslant 0 \cdot 12$ ). Host depth range did not relate with endoparasite 


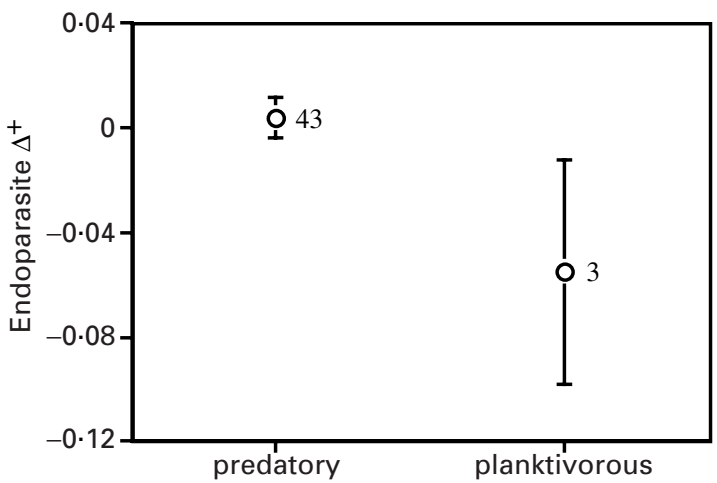

Fig. 4. Mean ( \pm s.E.) endoparasite taxonomic distinctness, $\Delta^{+}$, in fish species with different feeding habits. Measures of taxonomic distinctness are residuals of the regression of $\log \Delta^{+}$against $\log$ endoparasite species richness, and are thus corrected for species richness. Numbers of fish species in each category are shown on the graphs.

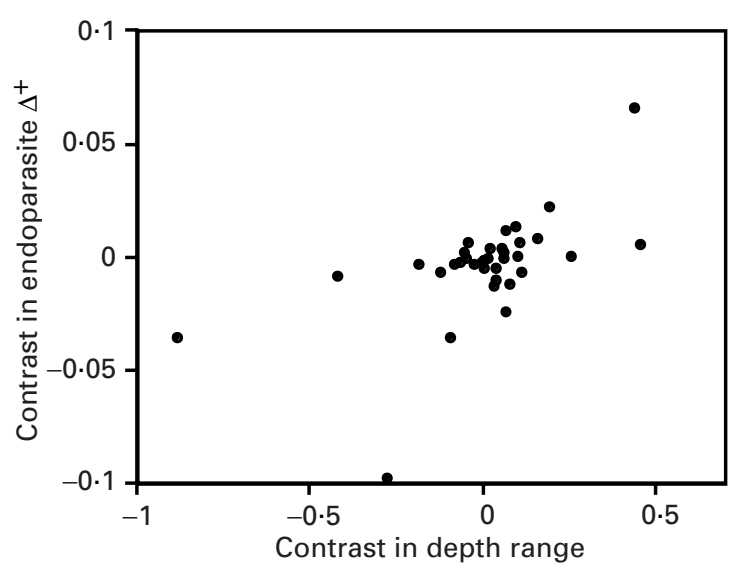

Fig. 5. Endoparasite taxonomic distinctness, $\Delta^{+}$ (corrected for species richness), as a function of host depth range across fish host species, based on 35 phylogenetically independent contrasts.

species richness $(P=0 \cdot 8145)$, but it correlated positively with $\Delta^{+}(r=0 \cdot 567, N=35$ sets of contrasts, $P=0.0002)$; 26 of the 35 sets of contrasts had the same sign, suggesting that the two variables tend to covary (Fig. 5). Thus, as a fish species extends its depth range, it also acquires a broader taxonomic range of endoparasites. There was no significant association between any of the categorical variables and either of the measures of endoparasite diversity, although, in the contrasts between schooling and non-schooling fish taxa, there was a hint that schooling fish had higher values of $\Lambda^{+}$than non-schooling taxa $(t=2 \cdot 062, N=8$ sets of contrasts, $P=0 \cdot 0781)$, as seen in the analysis using all parasite species.

\section{Diversity of ectoparasites}

No significant associations were found between any of the host features investigated and any of the three measures of ectoparasite diversity, using either raw species values or phylogenetically independent contrasts. There were, however, too few sets of contrasts to test the relationship between ectoparasite diversity and either feeding habits or schooling behaviour.

\section{DISCUSSION}

The search for the key determinants of parasite biodiversity has blossomed in recent years (see reviews in Poulin, 1997; Morand, 2000; Poulin \& Morand, 2000). At the same time, phylogenetic studies have revealed the historical and contemporary determinants of the biogeographical distribution of parasites (Hoberg \& Klassen, 2002). Yet, there is no consensus view regarding the role, if any, of various host traits in the evolutionary diversification of parasite faunas. This may in part be due to the nature of previous studies, which have often suffered from important limitations. Here, we found that parasite biodiversity was not distributed randomly among marine fish species with respect to host characteristics. We have addressed some features long thought to be associated with parasite acquisition in ecological time by individual fish, and over evolutionary time by fish species (see Dogiel, Petrushevski \& Polyanski, 1961). Certain host features, i.e. host body size and possibly host diet, appear to influence the total number of parasite species exploiting a host species, whereas other host features, i.e. depth range, appear to influence the variety of parasite taxa that a host will accumulate over evolutionary time. Our study includes two major improvements on earlier studies of this kind, making its results particularly interesting.

First, many earlier studies of the diversity of fish parasites have used data from fish species that do not occur in the same geographical areas (e.g., Bell \& Burt, 1991; Aho \& Bush, 1993 ; Poulin, 1995 ; Rohde, Hayward \& Heap, 1995; Gregory et al. 1996). While relationships between parasite diversity and host features may still be detected in such studies, they are confounded by the fact that the different fish species come from different areas and are therefore not exposed to the same pool of parasite species. The size of the pool of available parasite species must differ from one geographical area to the next, and thus it can limit how many parasite species a host can acquire over time, regardless of the characteristics of this host species. Our study focused on a set of fish species from the same general area (the coastal waters off the state of Rio de Janeiro, Brazil), thus minimizing any differences in parasite availability. In addition, our study was the first investigation of parasite biodiversity based on a representative data set of marine fishes from the Neotropical Region.

Second, previous studies have almost exclusively focused on parasite species richness as a measure of parasite diversity. While convenient, species richness does not capture all facets of biodiversity (Purvis \& 
Hector, 2000). Our analysis also included measures of the taxonomic diversity of parasite species in the different assemblages. Looking at Table 1, it is easy to find pairs of fish species with similar parasite species richness, but with different measures of parasite taxonomic distinctness, or vice versa. We can therefore look at whether certain host features have allowed some host species to 'capture' a narrow or a broad taxonomic range of parasite species, regardless of exactly how many parasite species they have acquired.

Fish size proved to be the main predictor of total parasite species richness in the marine fish we investigated. Based on arguments borrowed from island biogeography theory (Kuris et al. 1980), one might predict that the equilibrium number of parasite species that a host can harbour, when rates of colonization by new parasite species are balanced by extinction rates, should be determined mainly by its body size. Host body size is the best measure we can use for the total amount of nutrient or energy available in a host for parasite exploitation. Our results also suggest that host feeding habits may influence parasite species richness. Predatory fish should be exposed to more infective helminth larvae in their diet than planktivores; over evolutionary time, this should translate in higher parasite colonization rates in predatory fish than in planktivorous fish, pushing up the equilibrium parasite species richness.

Host feeding habits were also associated with the taxonomic diversity of endoparasite species. Clearly, predatory fish may not only acquire more parasites via their diet, they may also be exposed to a broader range of different parasite taxa. In contrast, fish schooling behaviour had no effect on parasite species richness, but it was associated, though weakly, with the taxonomic diversity of the parasite species exploiting a host species. Similarly, host depth range did not correlate with parasite species richness, but it covaried positively with the taxonomic diversity of endoparasites. This relationship was observed even when correcting for endoparasite species richness; thus, for a given number of parasite species, those of fish with broad depth range have wider taxonomic origins than those of fish with a limited depth range. A possibility may be that fish living at many depths feed on a wider array of prey species, and thus face colonization by a more diverse group of parasites, than fish restricted to a narrow depth zone.

On a larger scale, other determinants can influence the diversity of fish parasites in the region. The coastal area of Rio de Janeiro is strongly influenced by upwelling systems and by the subtropical convergence $\left(23^{\circ}-30^{\circ} \mathrm{S}\right)$, where the warm Brazilian Current (originating at the southernmost limit of the South Equatorial Current) meets the cold Falkland Current which flows northward (Braga, 2001). The water circulation pattern in this region impedes the exchanges of fish between the Caribbean Sea and the Brazilian coast. These conditions affect the fish species biodiversity in the area (Braga, 2001), and may also influence parasite biodiversity. Moreover, salinity levels, which drop near the Amazon River, may also limit the dispersal of fish and their parasites. Santos \& Carbonel (2000) proposed that between $10^{\circ} \mathrm{S}$ to $10^{\circ} \mathrm{N}$ along the South American coast, low salinity and water current patterns are limiting parasite dispersal. It is thus possible that the biodiversity of fish parasites around Rio de Janeiro may be constrained because physical barriers limit the arrival of further taxa.

All previous studies of parasite diversity in fish and other host taxa have focused exclusively on parasite species richness, the most convenient and widely available measure of biodiversity. Species richness conveys no information on the taxonomic structure of an assemblage. The measures of taxonomic distinctness used here provide a summary of this structure, and they suggest possible evolutionary scenarios. For instance, certain feeding habits or living over a broad depth range may facilitate hostswitches leading to completely novel host-parasite associations. For a given parasite species richness, this would lead to a taxonomically diverse assemblage. In contrast, parasites in host species with different features (narrow diet and depth range), may have accumulated in part via intra-host speciation, leading to a taxonomically closer set of species. These are only possibilities, of course. As shown by our results, however, shifting the focus from species richness to taxonomic diversity can cast a different light on the evolution of parasite biodiversity.

J.L.L. was partially supported by a Fellowship from CNPq (Conselho Nacional de Pesquisa e Desenvolvimento Tecnológico) and by two grants from FAPERJ (Fundação de Amparo à Pesquisa do Estado do Rio de Janeiro). R.P. was supported by a James Cook Research Fellowship from the Royal Society of New Zealand during this study.

\section{REFERENCES}

AHO, J. M. \& BUSH, A. O. (1993). Community richness in parasites of some freshwater fishes from North America. In Species Diversity in Ecological Communities : Historical and Geographical Perspectives (ed. Ricklefs, R. E. \& Schluter, D.), pp. 185-193. University of Chicago Press, Chicago.

Alves, D. R. \& LUQUE, J. L. (2001). Community ecology of the metazoan parasites of the white croaker

Micropogonias furnieri (Osteichthyes: Sciaenidae) from the coastal zone of the State of Rio de Janeiro, Brazil. Memórias do Instituto Oswaldo Cruz 96, 145-153.

Alves, D. R., LUQUe, J. L. \& PARAGUASsú, A. R. (2002a). Community Ecology of the Metazoan Parasites of Pink Cusk-eel, Genypterus brasiliensis (Osteichthyes: Ophidiidae), from the Coastal Zone of the State of Rio de Janeiro, Brazil. Memórias do Instituto Oswaldo Cruz 97, 683-689.

Alves, D. R., LuQue, J. L., PARAguassú, A. R., JORGE, D. S. \& VIÑAS, R. A. (2002b). Ecologia da comunidade de 
metazoários parasitos da abrótea Urophycis mystaceus (Osteichthyes: Phycidae) do litoral do Estado do Rio de Janeiro. Revista Brasileira de Zoociências 4, 19-30. AMIN, о. м. (1985). Classification. In Biology of the Acanthocephala (ed. Crompton, D. W. T. \& Nickol, B. B.), pp. 27-72. Cambridge University Press, Cambridge.

Anderson, R. C. (2000). Nematode Parasites of Vertebrates, 2nd Edn. CABI Publishing, Wallingford, UK.

APAKUPAKUl, K., SIDDALl, M. E. \& BURRESON, E. M. (1999).

Higher level relationships of leeches (Annelida: Clitellata: Euhirudinea) based on morphology and molecular gene sequences. Molecular Phylogenetics and Evolution 12, 350-359.

ARNEBERG, P. (2002). Host population density and body mass as determinants of species richness in parasite communities: comparative analyses of directly transmitted nematodes of mammals. Ecography 25, $88-94$.

BELL, G. \& BURT, A. (1991). The comparative biology of parasite species diversity: internal helminths of freshwater fish. Fournal of Animal Ecology 60, 1047-1064.

Beveridge, I., Chilton, N. B. \& SPRATT, D. M. (2002). The occurrence of species flocks in the nematode genus Cloacina (Strongyloidea: Cloacininae), parasitic in the stomachs of kangaroos and wallabies. Australian fournal of Zoology 50, 597-620.

BiZERril, C. R. S. F. \& CosTA, P. A. S. (2001). Peixes Marinhos do Estado do Rio de Faneiro. Fundação Estudos do Mar, Rio de Janeiro, Brazil.

Boeger, w. A. \& KRITSky, D. C. (1993). Phylogeny and a revised classification of the Monogenoidea Bychowsky, 1937 (Platyhelminthes). Systematic Parasitology 26, $1-32$.

BOXShall, G. A. \& MONTÚ, M. (1997). Copepods parasitic on Brazilian coastal fishes: A handbook. Nauplius 5, $1-225$.

BRAGA, A. C. (2001). O ambiente e a biodiversidade. In Peixes Marinhos do Estado do Rio de Faneiro (ed. Bizerril, C. R. S. F. \& Costa, P. A. S.), pp. 13-32. Fundação de Estudos do Mar, Rio de Janeiro.

BRooks, D. R. \& McLenNan, D. A. (1993). Parascript:

Parasites and the Language of Evolution. Smithsonian Institution Press, Washington, DC.

BUNKLEY-WILLIAMS, L. \& WILLIAMS Jr., E. H. (1998). Isopods associated with fishes: a synopsis and corrections. Fournal of Parasitology 84, 893-896.

BURT, A. (1989). Comparative methods using phylogenetically independent contrasts. Oxford Surveys in Evolutionary Biology 6, 33-53.

CARO, A., COMBES, C. \& EUZET, L. (1997). What makes a fish a suitable host for Monogenea in the Mediterranean? Fournal of Helminthology 71, 203-210.

CARPENTER, K. E., COLleTte, B. B. \& RUSSO, J. L. (1995). Unstable and stable classifications of scombroid fishes. Bulletin of Marine Science 56, 379-405.

Carvalho filho, A. (1999). Peixes : Costa Brasileira. Melro Publisher, São Paulo, Brazil.

CEZAR, A. D. \& LUQUE, J. L. (1999). Metazoan parasites of the Atlantic Spadefish, Chaetodipterus faber (Teleostei: Ephippidae) from the coastal zone of the State of Rio de Janeiro, Brazil. Fournal of the Helmintological Society of Washington 66, 14-20.
Chaves, N. D. \& LUQUE, J. L. (1999). Ecology of metazoan parasites of Menticirrhus americanus (Osteichthyes: Sciaenidae), coast area from Rio de Janeiro State, Brazil. Revista Brasileira de Parasitologia Veterinária 8 , 137-144.

CHEN, W.-J., BONILLO, C. \& LECOINTRE, G. (2003).

Repeatability of clades as a criterion of reliability: a case study for molecular phylogeny of Acanthomorpha (Teleostei) with larger number of taxa. Molecular Phylogenetics and Evolution 26, 262-288.

ClARKE, K. R. \& WARWICK, R. M. (1998). A taxonomic distinctness index and its statistical properties. Fournal of Applied Ecology 35, 523-531.

ClARKE, K. R. \& WARWICK, R. M. (1999). The taxonomic distinctness measure of biodiversity: weighting of step lengths between hierarchical levels. Marine Ecology Progress Series 184, 21-29.

ClARKE, K. R. \& WARWICK, R. M. (2001). A further biodiversity index applicable to species lists: variation in taxonomic distinctness. Marine Ecology Progress Series 216, 265-278.

CORDEIRO, A. S. \& LUQUE, J. L. (2004). Community ecology of the metazoan parasites of moon fish Selene setapinnis (Osteichthyes: Carangidae) from the coastal zone of the State of Rio de Janeiro, Brazil. Brazilian Fournal of Biology (in the Press).

DOBSON, A. P. \& ROBERTS, M. (1994). The population dynamics of parasitic helminth communities. Parasitology 109, S97-S108.

Dogiel, V. A., PETRUSHEVSKI, G. K. \& POLYANSKI, Y. I. (1961). Parasitology of Fishes. Oliver \& Boyd, Edinburgh.

felsenstein, J. (1985). Phylogenies and the comparative method. American Naturalist 125, 1-15.

Figueiredo, J. L. \& Menezes, N. A. (1978). Manual de Peixes Marinhos do Sudeste do Brasil II. Teleostei (1). Museu de Zoologia, Universidade de São Paulo, Brazil. figueiredo, J. L. \& Menezes, N. A. (1980). Manual de Peixes Marinhos do Sudeste do Brasil III. Teleostei (2).

Museu de Zoologia, Universidade de São Paulo, Brazil. figueiredo, J. L. \& Menezes, N. A. (2000). Manual de Peixes Marinhos do Sudeste do Brasil VI. Teleostei (5).

Museu de Zoologia, Universidade de São Paulo, Brazil. Froese, R. \& PAuly, D. (2003). FishBase. World Wide

Web electronic publication. www.fishbase.org, version 21, April 2003.

GARLAND, T. Jr., HARVEY, P. H. \& IVES, A. R. (1992).

Procedures for the analysis of comparative data using phylogenetically independent contrasts. Systematic Biology 41, 18-32.

GiBSON, D. I., JONES, A. \& BRAY, R. A. (2002). Keys to the Trematoda, vol. 1. CABI Publishing, Wallingford, $\mathrm{UK}$.

GREGORY, R. D., KEYMER, A. E. \& HARVEY, P. H. (1996).

Helminth parasite richness among vertebrates.

Biodiversity and Conservation 5, 985-997.

haIMOVICI, M., MARTINs, A. S. \& VIEIRA, P. C. (1996).

Distribuição e abundância de peixes teleósteos demersais sobre a plataforma continental do Sul do Brasil. Revista Brasileira de Biologia 56, 27-50.

HARVEY, P. H. \& PAGEL, M. D. (1991). The Comparative Method in Evolutionary Biology. Oxford University Press, Oxford.

HOBERG, E. P. \& KLASSEN, G. J. (2002). Revealing the faunal tapestry: co-evolution and historical biogeography of 
hosts and parasites in marine systems. Parasitology 124, S3-S22.

KENNEDY, C. R. \& BUSH, A. O. (1992). Species richness in helminth communities: the importance of multiple congeners. Parasitology 104, 189-197.

KHALIL, L. F., JONES, A. \& BRAY, R. A. (1994). Keys to the Cestode Parasites of Vertebrates. CABI International, Wallingford, UK.

KNOFF, M., LUQUE, J. L. \& AMATO, J. F. R. (1997). Community ecology of the metazoan parasites of grey mullets, Mugil platanus (Osteichthyes: Mugilidae) from the littoral of the State of Rio de Janeiro, Brazil. Revista Brasileira de Biologia 57, 441-454.

KURIS, A. M., BLAUSTEIN, A. R. \& ALIÓ, J. J. (1980). Hosts as islands. American Naturalist 116, 570-586.

LUQUE, J. L. \& CHAVES, N. D. (1999). Ecologia da comunidade de metazoários parasitos de Pomatomus saltator (Teleostei: Pomatomidae) do litoral do Estado do Rio de Janeiro. Revista Brasileira de Zoologia 16, 711-723.

LUQUE, J. L. \& ALVES, D. R. (2001). Ecologia das comunidades parasitárias do xaréu, Caranx hippos e do xerelete, Caranx latus (Osteichthyes: Carangidae) do litoral do Estado do Rio de Janeiro, Brasil. Revista Brasileira de Zoologia 18, 399-410.

Luque, J. L., AMATo, J. F. R. \& TAKEMOTO, R. M. (1996). Comparative analysis of the communities of metazoan parasites of Orthopristis ruber and Haemulon steindachneri (Osteichthyes: Haemulidae) from the southeastern Brazilian littoral: I. Structure and influence of the size and sex of hosts. Revista Brasileira de Biologia 56, 279-292.

LuQue, J. L., SOARES, F. P. \& Alves, D. R. (2002). Community ecology of the metazoan parasites of Argentine goatfish Mullus argentineus (Osteichthyes: Mullidae) from the coastal zone of the State of Rio de Janeiro, Brazil. Revista Brasileira de Parasitologia Veterinária 11, 33-38.

LuQue, J. L., SILVA, R. \& ALVES, D. R. (2003). Community ecology of the metazoan parasites of banded croaker Paralonchurus brasiliensis (Osteichthyes: Sciaenidae) from the coastal zone of the State of Rio de Janeiro, Brazil. Acta Scientiarum (in the Press).

Luque, J. L., ViÑas, R. A., PARAguassú, A. R. \& Alves, D. R. (2000). Metazoários parasitos das sardinhas Sardinella brasiliensis e Harengula clupeola (Osteichthyes: Clupeidae) do litoral do Estado do Rio de Janeiro, Brasil. Revista da Universidade Rural - Série Ciências da Vida 22, 71-76.

MacARThur, R. H. \& WiLson, E. O. (1967). The Theory of Island Biogeography. Princeton University Press, Princeton.

Menezes, N. A. \& Figueiredo, J. L. (1980). Manual de Peixes Marinhos do Sudeste de Brasil IV. Teleostei (3). Museu de Zoologia, Universidade de São Paulo, Brazil. menezes, N. A. \& Figueiredo, J. L. (1985). Manual de Peixes Marinhos do Sudeste de Brasil V. Teleostei (4). Museu de Zoologia, Universidade de São Paulo, Brazil.

MiYA, M., TAKEShIMA, H., ENDO, H., ISHIGURO, N. B., INOUE, J. G., MUKaI, T., SATOH, T. P., YAMAGUChI, M., KAWAGUCHI, A., MABUCHI, K., SHIRAI, S. M. \& NISHIDA, M. (2003). Major patterns of higher teleostean phylogenies: a new perspective based on 100 complete mitochondrial DNA sequences. Molecular Phylogenetics and Evolution 26, 121-138.
MORAn, M. D. (2003). Arguments for rejecting the sequential Bonferroni in ecological studies. Oikos 100, 403-405.

MORAND, s. (2000). Wormy world: comparative tests of theoretical hypotheses on parasite species richness. In Evolutionary Biology of Host-Parasite Relationships : Theory Meets Reality (ed. Poulin, R., Morand, S. \& Skorping, A.), pp. 63-79. Elsevier Science, Amsterdam. MORAND, S., CRIBB, T. H., KULBICKI, M., CHAUVET, C., DUfour, V., FALIEX, E., GALZIN, R., LO, C., LO-YAT, A., PICHELIN, S. P., RIGBY, M. C. \& SASAL, P. (2000).

Determinants of endoparasite species richness of New Caledonian Chaetodontidae. Parasitology 121, 65-73.

MORAND, s. \& POUlin, R. (1998). Density, body mass and parasite species richness of terrestrial mammals. Evolutionary Ecology 12, 717-727.

Nelson, J. S. (1994). Fishes of the World, 3rd Edn. Wiley, New York.

Page, R. D. M. (2003). Tangled Trees: Phylogeny, Cospeciation, and Coevolution. University of Chicago Press, Chicago.

PARAguassú, A. R., LUQUe, J. L. \& ALVES, D. R. (2002). Community ecology of metazoan parasites of red porgy Pagrus pagrus (Osteichthyes: Sparidae) from the coastal zone of the State of Rio de Janeiro, Brazil. Acta Scientiarum 24, 461-467.

PATERSON, A. M. \& GRAY, R. D. (1997). Host-parasite cospeciation, host switching, and missing the boat. In Host-Parasite Evolution: General Principles and Avian Models (ed. Clayton, D. H. \& Moore, J.), pp. 236-250. Oxford University Press, Oxford.

POULIN, R. (1995). Phylogeny, ecology, and the richness of parasite communities in vertebrates. Ecological Monographs 65, 283-302.

POULIN, R. (1997). Species richness of parasite assemblages: evolution and patterns. Annual Review of Ecology and Systematics 28, 341-358.

POULIN, R. (1998). Evolutionary Ecology of Parasites: From Individuals to Communities. Chapman and Hall, London.

POULIN, R. \& MORAND, S. (2000). The diversity of parasites. Quarterly Review of Biology 75, 277-293.

PRICE, P. W. \& ClANCY, K. M. (1983). Patterns in number of helminth parasite species in freshwater fishes. Fournal of Parasitology 69, 449-454.

PURVIS, A. \& HECTOR, A. (2000). Getting the measure of biodiversity. Nature, London 405, 212-219.

Purvis, A. \& Rambaut, A. (1994). Comparative Analysis by Independent Contrasts, CAIC version 2.0. Oxford University, Oxford.

Raibaut, A., COMBes, C. \& BeNoit, F. (1998). Analysis of the parasitic copepod species richness among Mediterranean fish. Fournal of Marine Systems 15, 185-206.

RANTA, E. (1992). Gregariousness versus solitude: another look at parasite faunal richness in Canadian freshwater fishes. Oecologia 89, 150-152.

ReEd, D. L., CARPENTER, K. E. \& Degravelle, M. J. (2002). Molecular systematics of the jacks (Perciformes: Carangidae) based on mitochondrial cytochrome $b$ sequences using parsimony, likelihood, and Bayesian approaches. Molecular Phylogenetics and Evolution 23, 513-524.

ROBERTS, M. G., DOBSON, A. P., ARNEBERG, P., DE LEO, G. A., KRECEK, R. C., MANFREDI, M. T., LANFRANCHI, P. \& ZAFfaroni, E. (2002). Parasite community ecology and 
biodiversity. In The Ecology of Wildlife Diseases (ed. Hudson, P. J., Rizzoli, A., Grenfell, B. T., Heesterbeek, H. \& Dobson, A. P.), pp. 63-82. Oxford University Press, Oxford.

ROGERS, S. I., ClARKE, K. R. \& REYNOLDS, J. D. (1999).

The taxonomic distinctness of coastal bottom-dwelling fish communities of the North-east Atlantic. Fournal of Animal Ecology 68, 769-782.

ROHDE, K., HAYWARD, C. J. \& HEAP, M. (1995). Aspects of the ecology of metazoan ectoparasites of marine fishes. International Fournal for Parasitology 25, 945-970.

SANTOS, C. P. \& CARBONEL, C. A. A. (2000). The role of physical factors in the distribution of the monogenean fauna in the midwestern and southwestern Atlantic. In Metazoan Parasites in the Neotropics: A Systematic and Ecological Perspective (ed. Salgado-Maldonado, G., Garcia-Aldrete, A. N. \& Vidal-Martinez, V. M.), pp. 61-75. Instituto de Biologia, UNAM, México.

SASAL, P. \& MORAND, S. (1998). Comparative analysis : a tool for studying monogenean ecology and evolution. International Fournal for Parasitology 28, 1637-1644.

SASAL, P., MORAND, S. \& GUÉGAN, J.-F. (1997). Determinants of parasite species richness in Mediterranean marine fish. Marine Ecology Progress Series 149, 61-71.

SCHAD, G. A. (1963). Niche diversification in a parasite species flock. Nature, London 198, 404-406.

Shimatani, K. (2001). On the measurement of species diversity incorporating species differences. Oikos 93, 135-147.

SILVA, L. G. O., LUQUe, J. L., ALVES, D. R. \& PARAgUassú, A. R. (2000). Ecologia da comunidade parasitária do peixeespada Trichiurus lepturus (Osteichthyes: Trichiuridae) do litoral do estado do Rio de Janeiro, Brasil. Revista Brasileira de Zoociências 2, 115-133.

TAKEMoto, R. M., LuQUe, J. L. \& AMATo, J. F. R. (1996). Comparative analysis of the metazoan parasite communities of leatherjackets, Oligoplites palometa, $O$ saurus and O. saliens (Osteichthyes: Carangidae) from
Sepetiba Bay, Rio de Janeiro, Brazil. Revista Brasileira de Biologia 56, 639-650.

TAVARES, L. E. R. \& LUQUe, J. L. (2004a). Community ecology of the metazoan parasites of common snook Centropomus undecimalis (Osteichthyes:

Centropomidae) from the coastal zone of the State of Rio de Janeiro, Brazil. Brazilian Fournal of Biology (in the Press).

TAVAres, L. E. R. \& LUQUe, J. L. (2004b). Community ecology of the metazoan parasites of White catfish Netuma barba (Osteichthyes: Ariidae) from the coastal zone of the State of Rio de Janeiro, Brazil. Brazilian Fournal of Biology 64, 1-8.

TAVARES, L. E. R., LUQUe, J. L. \& BOTElho NETO, S. L. (2001). Ecologia da comunidade parasitária do olho-de-cão, Priacanthus arenatus (Osteichthyes: Priacanthidae) do litoral do Estado do Rio de Janeiro, Brasil. Revista Brasileira de Zoociências 3, 45-59.

TAVARES, L. E. R., LUQUe, J. L. \& BICUdo, A. (2004a). Metazoan parasites of Brazilian menhaden Brevoortia aurea (Osteichthyes: Clupeidae) from the coastal zone of the State of Rio de Janeiro, Brazil. Brazilian Fournal of Biology (in the Press).

TAVARES, L. E. R., LUQUE, J. L. \& BICUdo, A. (2004b). Community ecology of the metazoan parasites of anchovy Anchoa tricolor (Osteichthyes: Engraulidae) from the coastal zone of the state of Rio de Janeiro, Brazil. Brazilian fournal of Biology (in the Press).

WAlther, B. A., COTGREAVE, P., PRICE, R. D., GREgory, R. D. \& Clayton, D. H. (1995). Sampling effort and parasite species richness. Parasitology Today 11, 306-310.

WARWICK, R. M. \& CLARKE, K. R. (2001). Practical measures of marine biodiversity based on relatedness of species. Oceanography and Marine Biology Annual Review 39, 207-231.

yamaguti, s. (1963). Parasitic Copepoda and Branchiura of Fishes. Interscience Publishers, New York. 